\title{
Corrosion of Well Casings in Compressed Air Energy Storage Environments
}

R. P. Elmore

J. A. Stottlemyre

October 1980

Prepared for the U.S. Department of Energy under Contract DE-AC06-76RLO 1830

Pacific Northwest Laboratory Operated for the U.S. Department of Energy

by Battelle Memorial Institute

J. A. Stotemyre 
NOTICE

This report was prepared as an account of work sponsored by the United States Government. Neither the United States nor the Department of Energy, nor any of their employees, nor any of their contractors, subcontractors, or their employees, makes any warranty, express or implied, or assumes any legal liability or responsibility for the accuracy, completeness or usefulness of any information, apparatus, product or process disclosed, or represents that its use would not infringe privately owned rights.

The views, opinions and conclusions contained in this report are those of the contractor and do not necessarily represent those of the United States Government or the United States Department of Energy.

\author{
PACIFIC NORTHWEST LABORATORY \\ operated by \\ BATTELLE \\ for the \\ UNITED STATES DEPARTMENT OF ENERGY \\ Under Contract DE-AC06-76RLO 1830
}

\author{
Printed in the United States of America \\ Available from \\ National Technical Information Service \\ United States Department of Commerce \\ 5285 Port Royal Road \\ Springfield, Virginia 22151
}

Price: Printed Copy $\$$

$\because$ Microfiche $\$ 3.00$

NTIS

-Pages Selling Price

001-025

026-050

$\$ 4.00$

051-075 \$5.25

$076-100 \quad-\$ 6.00$

$101-125 \quad \$ 6.50$

$126-150 \quad \$ 7.25$

$151-175 \quad \$ 8.00$

$176-200 \quad 59.00$

$201-225 \quad \$ 9.25$

$226-250 \quad \$ 9.50$

$251-275 \quad \$ 10.75$

$276-300 \quad \$ 11.00$ 


\title{
33679000544926
}

PNL -3429

UC-94e

CORROSION OF WELL CASINGS

IN COMPRESSED AIR ENERGY

STORAGE ENVIRONMENTS

\author{
R. P. Elmore \\ J. A. Stottlemyre
}

October 1980

Prepared for the U.S. Department of Energy under Contract DE-ACO6-76RLO 1830

Pacific Northwest Laboratory

Richland, Washington 99352 
. 


\section{FOREWORD}

The Compressed Air Energy Storage (CAES) Technology Program at the Pacific Northwest Laboratory (PNL) is sponsored by the Department of Energy (DOE), Divisions of Energy Storage Systems and Electric Energy Systems. The program scope includes a group of studies directed at developing a new energy storage technology to improve the cost and efficiency of electrical power utilization and to reduce the dependence on petroleum fuels such as oil and natural gas. The program has two major thrusts with the following objectives:

- Reservoir Stability Criteria - Develop design and stability criteria for long-term operation of underground reservoirs used for CAES to accelerate commercialization of the concept.

- Advanced Concepts Studies - Develop and assess advanced CAES concepts. that require little or no supplementary firing by petroleum fuels to el iminate CAES dependence on petroleum fuels.

The ultimate objective of this program is to reduce the consumption of natural gas and oil used for peak power generation plants by about $100 \mathrm{million}$ barrels per year. This objective could be accomplished by replacing conventional gas turbine-peaking plants currently in use with CAES plants.

A bibliography listing pertinent documents that have been published (or are to be published) has been provided. 


\section{ACKNOWLEDGMENTS}

This work was supported by the U.S. Department of Energy, Division of Thermal and Mechanical Energy Storage Systems of the Office of Advanced Conservation Technologies.

The authors would like to acknowledge the assistance of D. Ortiz and D. H. Getche11, who assisted with the autoclave tests; R. L. Erikson, who performed the $x$-ray diffraction analyses; and J. E. Coleman, who performed the electron microprobe analyses. 


\section{SUMMARY}

The goal of this study is to determine corrosive effects of compressed air energy storage (CAES) environments on several well casing materials to aid in material selections. Initially a literature search was conducted to obtain information on corrosion behavior of well casing materials in similar environments, and it was found that corrosion rates of 0.02-0.25 mi11imeters per year $(\mathrm{mm} / \mathrm{y})$ might be expected. This information was employed in designing the 1aboratory study. Unstressed electrically isolated samples of various carbon steels (A120, H40 series, and A53B) were autoclaved at varying humidities, temperatures, and exposure durations to simulate anticipated environments in the we 11 bore during CAES operation. A11 compressed air tests were run at 12.1 MPa. Temperatures varied between tests from a minimum of $323 \mathrm{~K}$ to a maximum of $573 \mathrm{~K}$, and humidity varied from $100 \%$ to completely dry air. The effects of salts in the humidified air were also studied.

Results of autoclave testing indicated that typical well casings of carbon steel as used in oil (H40 series), gas ( $A 120)$, and water (A53B) production wells adequately withstand the anticipated CAES reservoir environment. An acceptable corrosion rate arrived at by these laboratory simulations was between 0.0015 and $0.15 \mathrm{~mm} / \mathrm{y}$. Corrosion was caused by metal oxidation that formed a protective scale of iron oxide. Higher temperatures, humidity rates, or salinity content of the humid air increased corrosion. Corrosion also increased on a metal coupon in contact with a sandstone sample, possibly due to crevice corrosion. For each of these factors either singularly or collectively, the increased corrosion rates were still acceptable with the maximum measured at $0.15 \mathrm{~mm} / \mathrm{y}$.

When coupons were reused in an identical test, the corrosion rates increased (up to $0.20 \mathrm{~mm} / \mathrm{y}$ ) beyond the anticipated values that had been determined by extrapolation from "one-time" runs. Fine cracking of the protective scale probably occurred due to thermal variations, resulting in increased corrosion rates and a greater potential for particulates, which could plug the reservoir. Other conditions that could increase wel1 casing corrosion rates are flow rates in the well, metal-metal electrochemical interactions, and the presence of organics; however, these conditions were not investigated in this study. 
CONTENTS

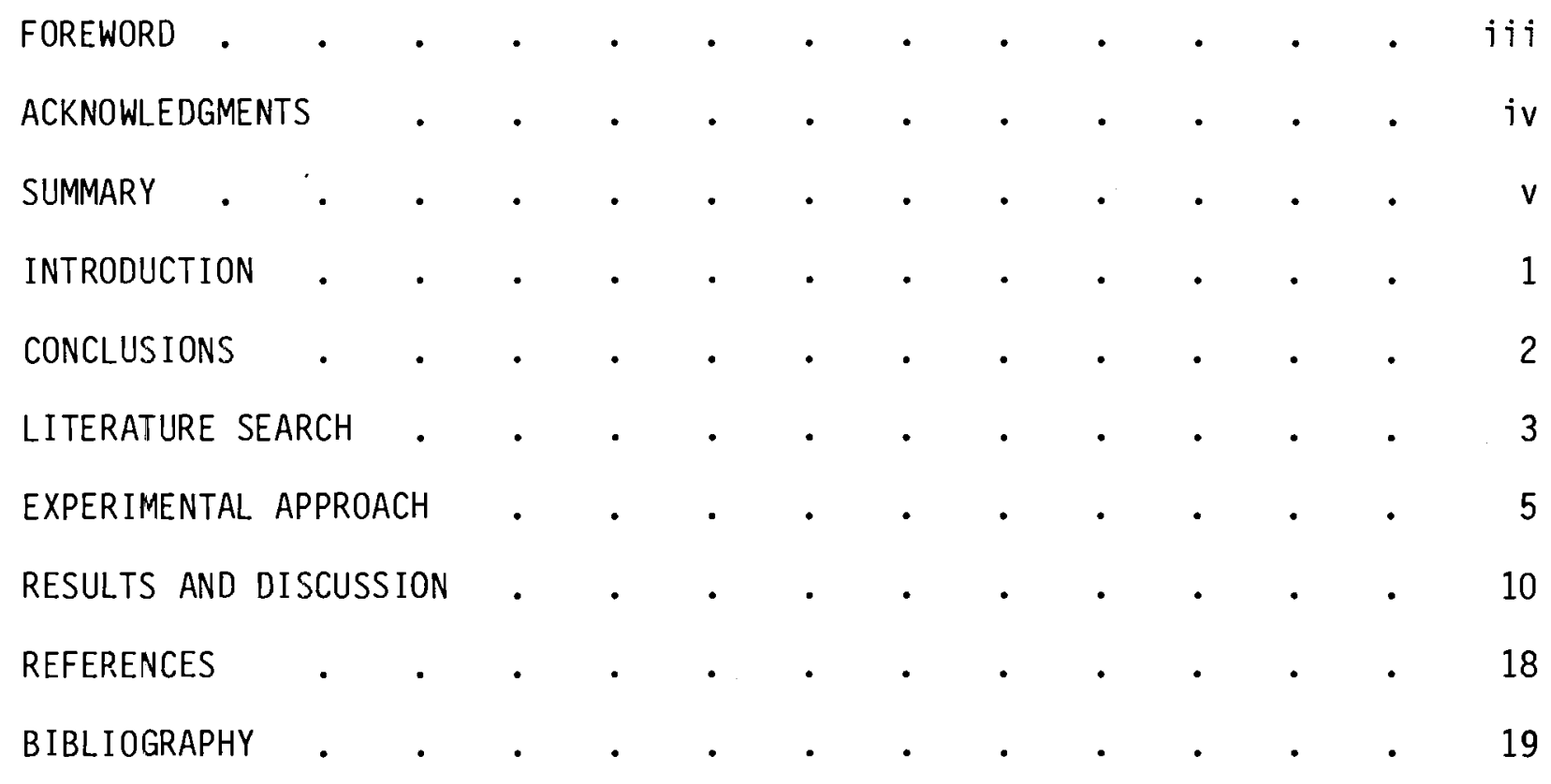


1 Experimental CAES Corrosion Facility . . . . . . 6

2 Hematite Scale on Casing Material . . . . . . . . 8

3 Corrosion as Weight Loss $(\mathrm{mg})$ per Surface Area $\left(\mathrm{cm}^{2}\right)$ Versus (a) Temperature, (b) Humidity, and (c) Hours

Exposed for Metal A120 . . . . . . . . . 12

4 Corrosion as Weight Loss (mg) per Surface Area $\left(\mathrm{cm}^{2}\right)$
Versus Hours Exposed for Metal A120. . . . . . . 14

5 Cross-Sectional Electron Microscopy of Corrosion Coupon . . . 15

\section{$\underline{\text { TABLES }}$}

1 Corrosion Under Environments Similar to CAES . . . . . 4

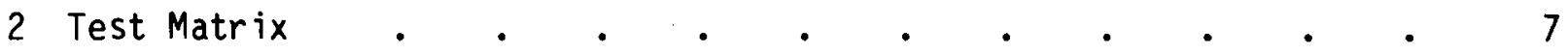

3 Corrosion Rates of Casing Materials Under Simulated CAES Environment 11

4 Corrosion Rates (mm/y) for Casing Materials Exposed in a 100\% Humidity Environment Produced from Salt Solution Reservoir . . 16 


\section{INTRODUCTION}

In this study typical well casings as used in the water, oil, and gas industries were exposed to anticipated compressed air energy storage (CAES) environments to determine their acceptability. Since CAES is a new technology, the performance of well casings in contact with CAES production environments is not yet known. It was hoped that this study would verify that inexpensive carbon steel well casings that are used in other industries would also be sufficient for this environment.

The initial phase of this program was a literature study on casing corrosion in environments similar to CAES. Laboratory tests were then designed from this information. The final results of this study were measurements of corrosion for three casing metals as a function of exposure time, temperature, humidity, vapor salinity, and cycling. 


\section{CONCLUSIONS}

Typical well casings of carbon steel as used in 011 , gas, and water production wells appear to withstand anticipated CAES reservoir environments adequately. An estimated acceptable corrosion rate of between 0.0015 and $0.20 \mathrm{~mm} / \mathrm{y}$ was arrived at by laboratory simulations. The corrosion, caused by metal oxidation, formed a protective scale of iron oxide that at first appeared to be beneficial. However, it was discovered that the scale is a potential source of particulates.

During cycling tests it was noted that corrosion rates increased beyond anticipated values that had been determined by extrapolation of corrosion rates from one-time runs. Fine cracking of the protective scale probably occurred during thermal expansion and contraction, which would allow air and water easier access to the metal. In addition, cracking of the scale would greatly increase the potential for particulates.

The corrosion rate was primarily controlled by the formation of the protective scale, thus the corrosion rate decreased with time. of the other parameters that were varied, temperature had the most dramatic effect on increasing corrosion rates. Increasing humidity or salinity produced minor increases in corrosion rates, and corrosion rates were also higher at the sandstone-metal interface.

In conclusion, well casings composed of metals A120, H40 series, and A53B appear to corrode at acceptable rates in anticipated CAES reservoir environments. Factors that increase corrosion are: temperature, humidity, salinity of the humid air, sandstone-metal interactions, and any cracking or partial removal of the protective scale.

Other conditions that could increase corrosion rates are flow rates in the well, metal-metal electrochemical interactions, and the presence of organics; these factors were not investigated in this study. It is suggested that coupons be placed in accessible locations in the wells for actual field measurements of corrosion or alternately that in-line corrosion probes be installed. 


\section{LITERATURE SEARCH}

The literature was examined for data on well casing corrosion under environments similar to that during CAES production; corrosion data for potential materials are presented in Table 1. Air temperature applicable to CAES may be in the range of $325-573 \mathrm{~K}$, and medium storage pressures of 3.5 to $12.1 \mathrm{MPa}$ are being contemplated. During the initial phase of air bubble development extraction, 100\% humidity conditions can be expected. Subsequent reservoir dewatering with hot undersaturated air will result in humidity decreases with time, but a finite amount of water vapor will be present in the air stream for several years and possibly for the lifetime of the plant (Stottlemyre et al. 1979). Corrosion data for aerated steam represent the high-humidity phase, and data for separated (undersaturated) steam simulate the low-humidity stages of CAES plant operation. It appears that high corrosion rates--up to $0.51 \mathrm{~mm} / \mathrm{y}$ or 20 mils per year (mpy)--might be expected under high-humidity conditions (Marshall and Hugill 1957). Electrochemical attack is moisture dependent; and, therefore, as the humidity decreases, the corrosion rates should also decrease. Corrosion rates between $0.02-0.25 \mathrm{~mm} / \mathrm{y}$ might be expected.

In all literature cases, corrosion is characterized as general corrosion that produces an uneven surface. Stressed samples have been tested in aerated steam and separated steam (Marshall and Hugill 1957; Foster, Marshall, and Tombs 1964), and as expected the samples did not produce cracks. Thus, it appears that the form of casing deterioration expected in the CAES environment can also be characterized as a general corrosion attack. 
TABLE 1. Corrosion Under Environments Similar to CAES

\begin{tabular}{|c|c|c|c|}
\hline Metal & Condition & $\begin{array}{l}\text { Corrosion } \\
\text { Rate, mpy }\end{array}$ & Reference \\
\hline $\begin{array}{l}\text { Carbon Steel } \\
\text { ASTM-A285 }\end{array}$ & $\begin{array}{l}\text { Aerated steam, } 150 \text { days } \\
100^{\circ} \mathrm{C}, 1 \mathrm{~atm} \text {, velocity } \\
10 \mathrm{~m} / \mathrm{sec}\end{array}$ & 4 & $\begin{array}{l}\text { Tolivia, Hoaski, and } \\
\text { Miyazaki } 1975\end{array}$ \\
\hline Carbon Steel & $\begin{array}{l}\text { Aerated steam, } 144 \text { days, } \\
30-1 b \text { steam to } 2-16 \text { air }\end{array}$ & 20 & Marshall and Hugill 1957 \\
\hline Carbon Stee 1 & $\begin{array}{l}\text { Separated steam, } \\
144 \text { days, } 140^{\circ} \mathrm{C}\end{array}$ & 6 & Marshall and Hugill 1957 \\
\hline $\begin{array}{l}\text { Bore Casings } \\
\text { API-355 }\end{array}$ & $\begin{array}{l}\text { Aerated steam, } 144 \text { days, } \\
98-108^{\circ} \mathrm{C}, 0-5 \text { psig }\end{array}$ & $<10$ & $\begin{array}{l}\text { Foster, Marshall, and } \\
\text { Tombs } 1964\end{array}$ \\
\hline AP I-H40 & $\begin{array}{l}\text { Aerated steam, } 144 \text { days, } \\
98-108^{\circ} \mathrm{C}, 0-5 \text { psig }\end{array}$ & $<10$ & $\begin{array}{l}\text { Foster, Marshall, and } \\
\text { Tombs } 1964\end{array}$ \\
\hline API -355 & $\begin{array}{l}\text { Separated steam, } \\
144 \text { days, } 142-162{ }^{\circ} \mathrm{C} \\
10 \% \text { moisture, } 8-40 \text { psig }\end{array}$ & $1-10$ & $\begin{array}{l}\text { Foster, Marshal1, and } \\
\text { Tombs } 1964\end{array}$ \\
\hline API-H40 & $\begin{array}{l}\text { Separated steam, } \\
144 \text { days, } 142-162^{\circ} \mathrm{C} \text {, } \\
10 \% \text { moisture, } 8-40 \text { psig }\end{array}$ & $1-10$ & $\begin{array}{l}\text { Foster, Marshall, and } \\
\text { Tombs } 1964\end{array}$ \\
\hline $\begin{array}{l}\text { Carbon Steel } \\
\text { AISI } 1060\end{array}$ & $\begin{array}{l}\text { Separated demisted steam, } \\
171^{\circ} \mathrm{C}, 110 \mathrm{psig}, \\
150 \text { days plus } 10 \text { days } \\
\text { air/moisture }\end{array}$ & 1.3 & $\begin{array}{l}\text { Toney, Cohen, and } \\
\text { and Cron } 1977\end{array}$ \\
\hline
\end{tabular}




\section{EXPERIMENTAL APPROACH}

For this preliminary study on the corrosive effects of CAES environments on well casings, three typical well casing alloys were chosen for testing. The specimens were cut from 3-in. A120 (gas well casing), 4-in. H40 series (oil well casing), and 6-in. A53B (water well casing) pipes and were approximately $2.54 \times 2.54 \times 0.65 \mathrm{~cm}$, with a surface area averaging $19.25 \mathrm{~cm}^{2}$. The surfaces of the specimens were first cleaned in CP-9 (500-ml HCl, 500-ml $\mathrm{H}_{2} \mathrm{O}$, plus 12.5-ml formaldehyde) to remove any initial rust as well as the protective zinc coating on $A 120$ coupons. The specimens were hung on Teflon ${ }^{(}-$ insulated hangers and then placed in titanium autoclaves. Due to the highly oxidizing environment associated with CAES experiments all valves and piping were fabricated from titanium. Figure 1 shows the experimental facility; the recorder, which is located a short distance from the autoclaves, is not shown.

The experimental test matrix is presented in Table 2. Unstressed electrically isolated samples of various carbon steels were autoclaved in varying humidities, temperatures, and exposure durations. Initially the tests ran between 168 and 366 hours, but a few tests were extended to 700 hours. Al1 compressed air tests were run at $12.1 \mathrm{MPa}$. The temperatures varied between tests from a minimum of $323 \mathrm{~K}$ to a maximum of $573 \mathrm{~K}$. Humidity varied from $100 \%$ (the initial field condition) to completely dry air (a potential final field condition) and was controlled by the amount of water initially added to the vessel. The compressed air was mixed from water-free components (dew point $200 \mathrm{~K})$, and the autoclaves were preheated to bake out any moisture in them prior to the test. After the specimens were sealed in the autoclaves, dry compressed air was flushed through the system to sweep out any moisture to insure that the $0 \%$ humidity tests were totally water-free. For the $100 \%$ humidity tests excess water was added to each autoclave to insure saturation throughout the test even though slight leaks of ten occurred. The tests at $50 \%$ humidity had a controlled water-to-air ratio; therefore, no leaks were permissible, which was not easy to attain. The results of one successful $50 \%$

(8) Trademark of E. I. du Pont de Nemours and Company, Inc., Wilmington, Del aware. 


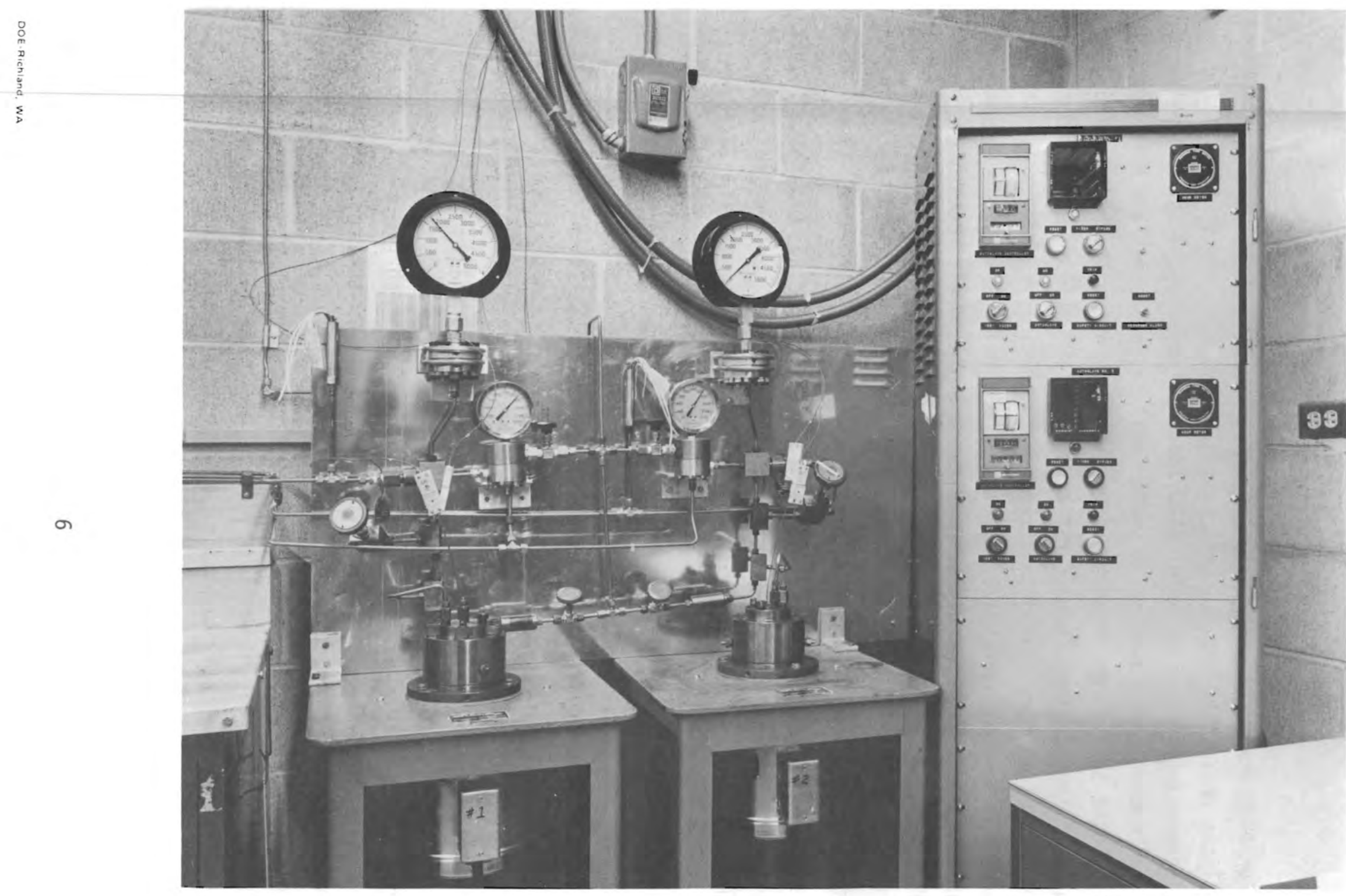

FIGURE 1. Experimental CAES Corrosion Facility 
TABLE 2. Test Matrix

\begin{tabular}{|c|c|c|c|c|}
\hline Trial & Run & Temperature, $\mathrm{K}$ & Humidity, \% & Duration, $h$ \\
\hline 1 & 9 & 323 & 0 & 168 \\
\hline 2 & 15 & 323 & 0 & 336 \\
\hline 3 & 5 & 323 & 50 & 168 \\
\hline 4 & 17 & 323 & 50 & 336 \\
\hline 5 & 1 & 323 & 100 & 168 \\
\hline 6 & 4 & 323 & 100 & 336 \\
\hline 7 & 10 & 448 & 0 & 168 \\
\hline 8 & 16 & 448 & 0 & 336 \\
\hline 9 & 2 & 448 & 50 & 168 \\
\hline 10 & 8 & 448 & 50 & 336 \\
\hline 11 & 13 & 448 & 100 & 168 \\
\hline 12 & 3 & 448 & 100 & 336 \\
\hline 13 & 14 & 573 & 0 & 168 \\
\hline 14 & 11 & 573 & 0 & 336 \\
\hline 15 & 18 & 573 & 50 & 168 \\
\hline 16 & 7 & 573 & 50 & 336 \\
\hline 17 & 6 & 573 & 100 & 168 \\
\hline 18 & 12 & 573 & 100 & 336 \\
\hline $19^{(a)}$ & 19 & 573 & 100 & 336 \\
\hline $20^{(b)}$ & 20 & 448 & 100 & 336 \\
\hline $21^{(b)}$ & 21 & 573 & 100 & 336 \\
\hline
\end{tabular}

(a) Standstone core in contact with metal specimen.

(b) Additional tests using a salt solution as the reservoir for producing humidity.

humidity test (no leaks) were similar to those of the 100\% humidity test, qualitatively implying that there were no significant differences between 50 and $100 \%$ humidity conditions. Thus, the cost/benefit of the $50 \%$ humidity tests was deemed questionable and these experiments were eliminated. As a substitute, $100 \%$ humidity tests were conducted using a salt solution as the reservoir water to measure the effects of salts upon corrosion rates in humidified air. 
At the completion of each test the specimens were placed in a desiccator to dry and then reweighed. In all cases the weight of the specimen either remained constant or increased, which was due to the formation of scale--a corrosion product. The scale coverage varied, ranging from patchy to complete. The scale was mostly a reddish color, but after some tests the coupons were black with reddish patches. X-ray diffraction analyses of the red scale identified it as hematite, and Figure 2 shows the typical patchy hematite scale. To determine the weight loss for the specimens the scale had to be removed without removing significant quantities of the metal, which was accomplished successfully with the cleaning solution CP-9. After treatment with CP-9 the coupons were rinsed in water, rinsed with acetone, and then placed in a desiccator. For each of the three pipe metals tested, three blanks of each metal were treated with the cleaning solution in the same manner as during descaling to determine the metal lost during this procedure.

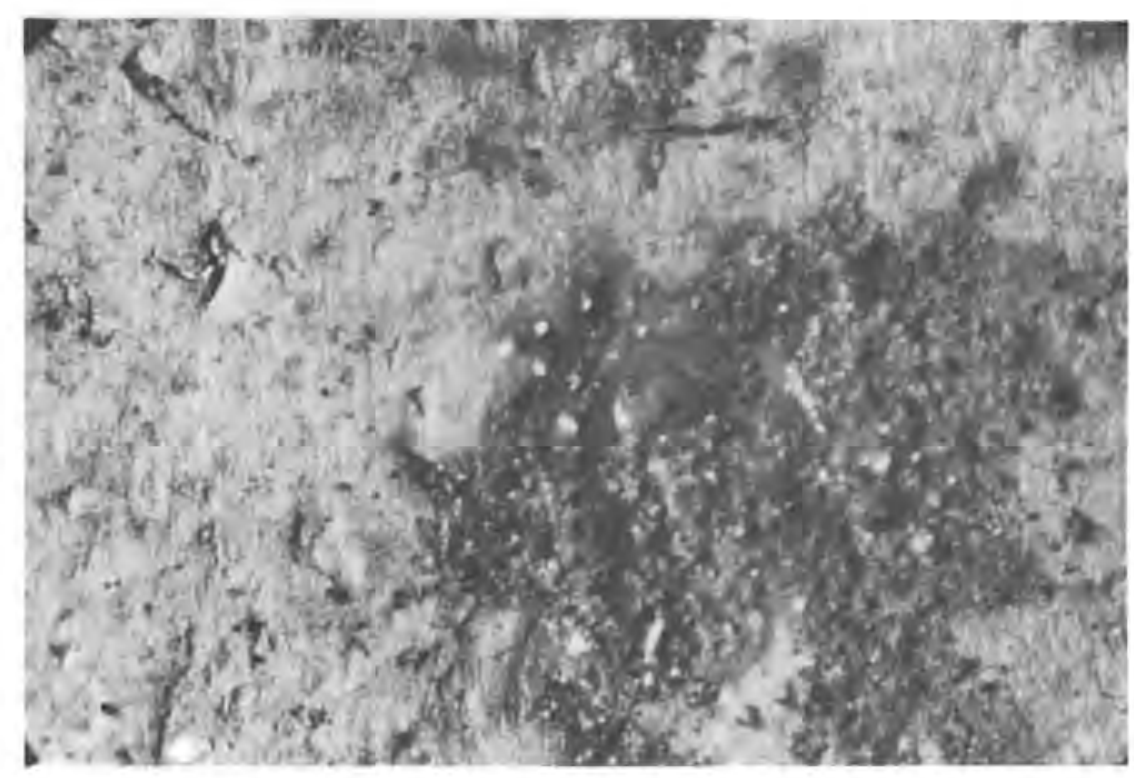

FIGURE 2. Hematite Scale on Casing Material (Test Conditions: $323 \mathrm{~K}, 100 \%$ Humidity, 504 Hours) 
An average of $0.0008 \mathrm{~g}$ was lost for $\mathrm{A} 53 \mathrm{~B}$ pipe specimens; $0.0006 \mathrm{~g}$, for $\mathrm{H} 40$ series; and $0.0009 \mathrm{~g}$, for $A 120$. Weight loss was determined by the difference between the initial sample weight and the weight after descaling (post weight) plus the weight correction. Some samples were not descaled; instead these were reused in a test with the same conditions to extend the coupon exposure time.

Due to their irregular shape the surface area of each specimen was calculated using a computer program. Since the specimens were actual pipe sections, they had a curvature that complicated surface area calculations. For each specimen, eight measurements were taken to within $0.00025 \mathrm{~cm}$ for area calculations. The area for the hole was substracted from the total surface area.

From the weight loss data and the surface area calculations the corrosion rate in millimeters per year was determined by the following equation:

$$
\mathrm{mm} / \mathrm{y}=\mathrm{mpy}(0.0254)=\frac{(526,800) \text { (weight loss, grams) }}{\left(\text { area, in. }{ }^{2}\right)(\text { density, } \mathrm{g} / \mathrm{cc})(\text { time, } h)}
$$




\section{RESULTS AND DISCUSSION}

Corrosion rates for various test conditions for the three metals are summarized in Table 3 . The rates are mean values in mils per year \pm 1 standard deviation, and the number of samples in each averaged data point is given in parentheses. The metal corrosion rates were averaged and are listed for each test. The averaged corrosion rates ranged from a 1 ow of $0.0015 \mathrm{~mm} / \mathrm{y}(0.06 \mathrm{mpy}$, $323 \mathrm{~K}, 0 \%$ humidity) to a maximum of $0.14 \mathrm{~mm} / \mathrm{y}(5.65 \mathrm{mpy}, 573 \mathrm{~K}, 100 \%$ humidity). Initial corrosion rates start as high as $0.08 \mathrm{~mm} / \mathrm{y}$ ( $3 \mathrm{mpy}$ ) for $0 \%$ humidity cases but rapidly decrease to around $0.025 \mathrm{~mm} / \mathrm{y}(1 \mathrm{mpy})$ after 300 hours. Most of the $100 \%$ humidity cases do not decrease to $0.025 \mathrm{~mm} / \mathrm{y}$ ( $1 \mathrm{mpy}$ ) until after almost 500 hours. For both 0 and $100 \%$ humidity the $573 \mathrm{~K}$ cases display the highest corrosion rates. The three types of casing material--Al20, H40 series, and $A 53 B$--behave in a similar manner in all environments with corrosion rates increasing with higher temperatures and humidity rates. In most instances, corrosion rates decrease with exposure time.

Corrosion (weight loss/surface area) as a function of temperature, humidity, and exposure was plotted for A120 (Figure 3) to demonstrate graphically how these parameters affect corrosion. Since the metals behave similarly, only one metal will be detailed. Among the three variables (temperature, humidity, and exposure time) humidity had the smallest effect toward increasing corrosion, see Figure $3(\mathrm{~b})$. Corrosion continually increased with temperature, Figure $3(\mathrm{a})$, and rose most rapidly between 448 and $573 \mathrm{~K}$. The relationship between corrosion and exposure was the most interesting: As exposure time increased, the rate at which corrosion increased leveled off, implying that a protective coating was forming on the metal surfaces.

Recycling also increased corrosion of the coupons. Corrosion rates for one-time tested coupons ranged between $0.0015-0.08 \mathrm{~mm} / \mathrm{y}$ while the range for retested coupons was from 0.01 to $0.20 \mathrm{~mm} / \mathrm{y}$. For each temperature and humidity condition a coupon was retested with the corrosion scale undisturbed. In each case corrosion was higher than would be inferred from extrapolation of the original corrosion data to these times. Figure 4 illustrates these trends for A120. In the graph the disconnected points are coupons that were used in the 
TABLE 3. Corrosion Rates of Casing Materials Under Simulated CAES Environment

\begin{tabular}{|c|c|c|c|c|c|c|c|c|c|c|}
\hline \multirow{2}{*}{\multicolumn{3}{|c|}{$\begin{array}{l}\text { TEMPERATURE } \\
\text { HUMIDITY }\end{array}$}} & \multicolumn{8}{|c|}{$573 \mathrm{~K}$} \\
\hline & & 336 & $\begin{array}{l}100 \% \\
351\end{array}$ & 384 & 690 & 699 & 168 & 286 & 306 & 336 \\
\hline Al2O & $1.61 \pm 0.70(2)$ & 4. $82(1)^{\circ}$ & $5.99(1)^{\circ}$ & $1.54 \pm 0.59(2)$ & $0.98(1)$ & $5.19(1 \%$ & 3. $21 \pm 1.10(3)$ & $1.22 \pm 0.34(3)$ & $0.62 \pm 0.14(2)$ & l. $23 \pm 0.23(3)$ \\
\hline H40 SERIES & $1.62 \pm 0.24(2)$ & $7.89 \pm 0.11(2)^{\star}$ & $\cdots$ & 1. 37 (1) & $1.47(1)$ & --- & $2.65 \pm 0.05(2)$ & $1.60 \pm 0.14(3)$ & $0.77 \pm 0.12$ & $0.89 \pm 0.37(3)$ \\
\hline A53B & $1.49 \pm 0.18(2)$ & $3.82 \pm 252(2 \%$ & --- & $227(1)$ & $1.71(1)$ & $2.73(1)^{\infty}$ & $2.51 \pm 0.96(3)$ & $1.19 \pm 0.32(3)$ & $0.77 \pm 0.16$ & 1. $05 \pm 0.32$ (3) \\
\hline AVERAGE & $(1.57 \pm 0.35(6)$ & $(5.65 \pm 0.24(5)$ & & $(1.68 \pm 0.53(4)$ & $(1.39 \pm 0.37$ (3) & $(3.96 \pm 1.74(2)$ & $(281 \pm 0.85(3)$ & (1. $34 \pm 0.32(9)$ & $(0.73 \pm 0.14(8)$ & $(1.06 \pm 0.33(9)$ \\
\hline
\end{tabular}

\begin{tabular}{|c|c|c|c|c|c|c|c|}
\hline $\begin{array}{l}\text { TEMPERATURE } \\
\text { HUMIDITY } \\
\text { HOURS }\end{array}$ & 312 & $\begin{array}{l}100 \% \\
504\end{array}$ & 816 & $\begin{array}{l}448 K K \\
50 \% \\
168\end{array}$ & 216 & $\begin{array}{l}0 \% \\
335\end{array}$ & 551 \\
\hline Al2O & $1.07+0.49(2)$ & $0.70(1)$ & 1. $40(1)^{\mathrm{kat}}$ & 1. $39 \pm 0.15(3)$ & $0.73 \pm 0.04(2)$ & 1. $10 \pm 0.08(2)$ & $0.77(1)^{*}$ \\
\hline H40 SERIES & $0.99 \pm 0.13(2)$ & $1.07(1)$ & $1.33(1)^{*}$ & $1.50 \pm 0.65(3)$ & 1. $01 \pm 0.39(2)$ & $0.8 \mathrm{u} \pm 0.20(2)$ & $0.84(1)^{*}$ \\
\hline A538 & $1.36 \pm 0.20(2)$ & $0.91 \pm 0.05(2)$ & $1.31(1)^{*}$ & $0.47 \pm 0.14(3)$ & $0.80 \pm 0.37(2)$ & $0.34 \div 0.00(2)$ & $0.94(1)=$ \\
\hline AVERAGE & $(1.14 \pm 0.19(6)$ & $(0.90 \pm 0.15(4)$ & $(1.35 \pm 0.05(3)$ & (1. $12 \pm 0.059(9)$ & $(0.84 \pm 0.27(6)$ & $(0.75 \pm 0.35(6)$ & $(0.85 \pm 0.09(3)$ \\
\hline
\end{tabular}

\begin{tabular}{|c|c|c|c|c|c|c|}
\hline $\begin{array}{l}\text { TEMPERATURE } \\
\text { HUMIDITY } \\
\text { HOURS }\end{array}$ & 350 & $\begin{array}{l}100 \% \\
504\end{array}$ & 854 & 169 & $\begin{array}{l}0 \% \\
350\end{array}$ & 519 \\
\hline Al20 & $0.11 \pm 0.06(2)$ & $0.61(1)$ & $0.67(1)^{\circ}$ & $3.05 \pm 0.81(2)$ & $0.06 \pm 0.02(2)$ & $0.87(1)^{*}$ \\
\hline H4O SERIES & $0.26 \pm 0.08(2)$ & 1.47 (1) & $0.56(1)^{\circ}$ & $2.71 \pm 0.13(2)$ & $0.15 \pm 0.07(2)$ & $0.78(1)^{*}$ \\
\hline A53B & $0.24 \pm 0.10(2)$ & $0.73 \pm 0.04(2)$ & $0.51(1)^{\circ}$ & $2.51 \pm 0.76(2)$ & $0.09 \pm 0.00(2)$ & $0.42(1)^{t}$ \\
\hline AVERAGE & (0. $20 \pm 0.10(6)$ & $(1.15 \pm 0.68(5)$ & $(0.85 \pm 0.08(3)$ & $(2.76 \pm 0.56(6)$ & $(0.10 \pm 0.05(6)$ & $(0.69 \pm 0.24$ \\
\hline
\end{tabular}

THE RATES ARE MEAN VALUES IN MILS PER YEAR PLUS OR MINUS ONE STANDARD DEVIATION. THE NUMBER OF SAMPLES IN EACH AVERAGED DATA IS GIVEN IN THE PARENTHESIS. FOR EACH TEST THE THREE METALS WERE AVERAGED.

* COUPON IN CONTACT WITH SANDSTONE

* RETESTED COUPONS 

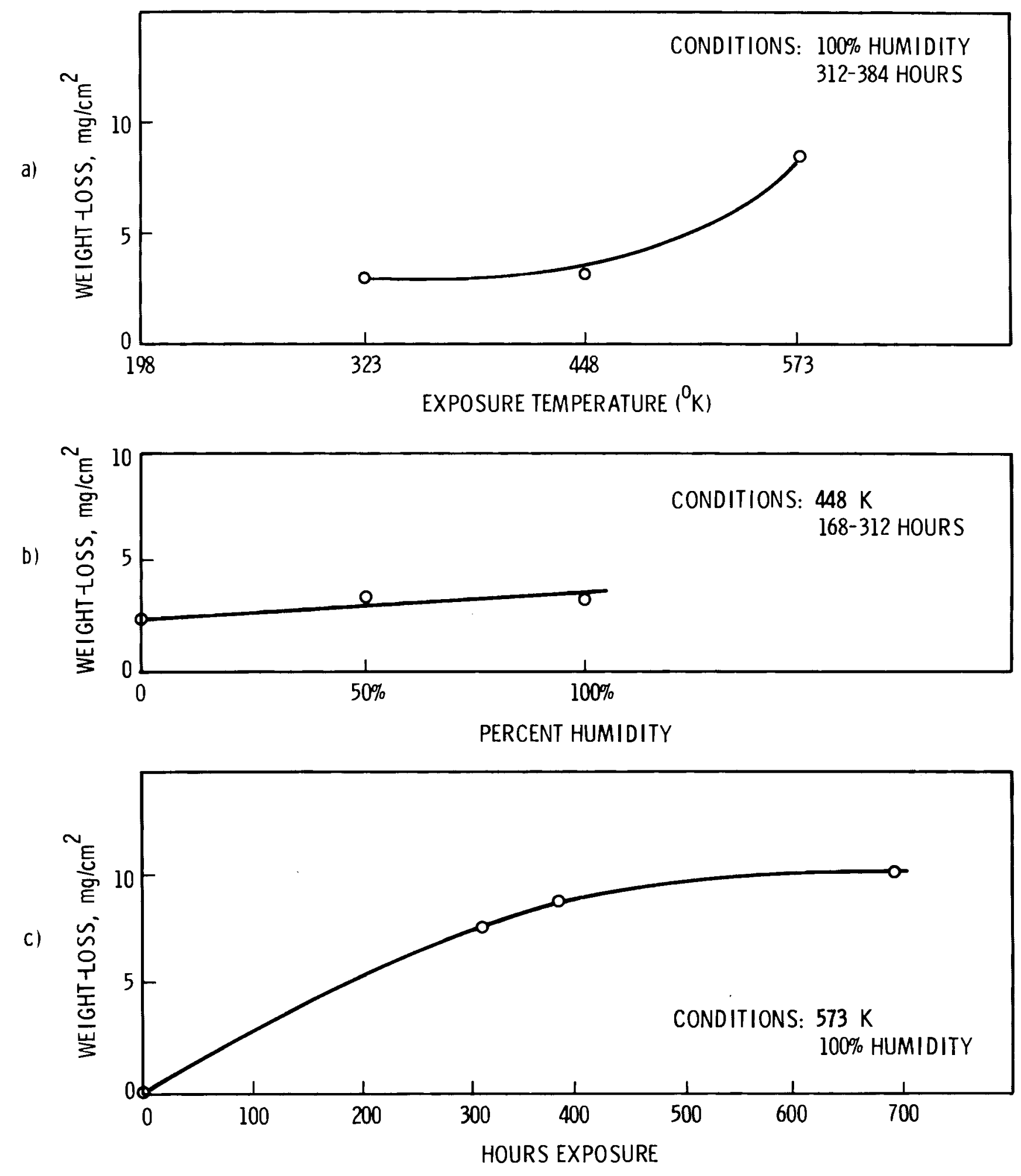

FIGURE 3. Corrosion as Weight Loss (mg) per Surface Area $\left(\mathrm{cm}^{2}\right)$ Versus (a) Temperature, (b) Humidity, and (c) Hours Exposed for Metal A120 
indicated conditions ( $i . e ., \nabla=573 \mathrm{~K}, 100 \%$ humidity) and then reused in the same environment in a later test. It can be seen that the rate at which corrosion increased beyond the expected extrapolated value rose with temperature. Thus, temperature or humidity cycling affects the resilience of the metals to corrosion. Fine cracking of the protective scale probably occurred during the thermal expansion and contraction between tests, increasing the possibility for oxidation.

A sample from each of the test series was cross sectioned and examined by electron microscopy to determine the thickness, chemistry, and structure of the corrosion products. The results were similar among the coupons; thus, just one sample is presented: Coupon 329, 448K, 100\% humidity, 504 hours. As shown in Figure 5 , the corrosion product is iron that was determined to be an iron oxide, which is also implied by its smaller iron peak when compared to the metals. The more important observation is the solidity of the scale; this dense iron-oxide corrosion product apparently formed a protective cover so that corrosion rates reduced with time.

The scale was also tested for its cohesiveness to the metal, which is important because sandblasting could occur in the well during high airflow and produce loose scale fragments. Similar scale fragments have plugged pore spaces in the reservoir and/or formed sandface filter cakes, thus reducing the air injectivity of the well and surrounding zones (Barkman et al. 1972; Owen et al. 1979). The scale on the coupons exposed in $323 \mathrm{~K}$ environments was the easiest to remove; with higher temperatures the scale was more cohesive except when it became thicker and flakier and thus easier to remove. The amount of potential particulates was quickly estimated at $42 \mathrm{~g}$ for 1 day (using the 448K, dry air test, which produces approximately $1 \mathrm{mg}$ of scale per $20 \mathrm{~cm}^{2}$ area) for a well $20 \mathrm{~cm}$ in diameter and $1200 \mathrm{~m}$ deep. No estimate of particle size distribution was attempted. 


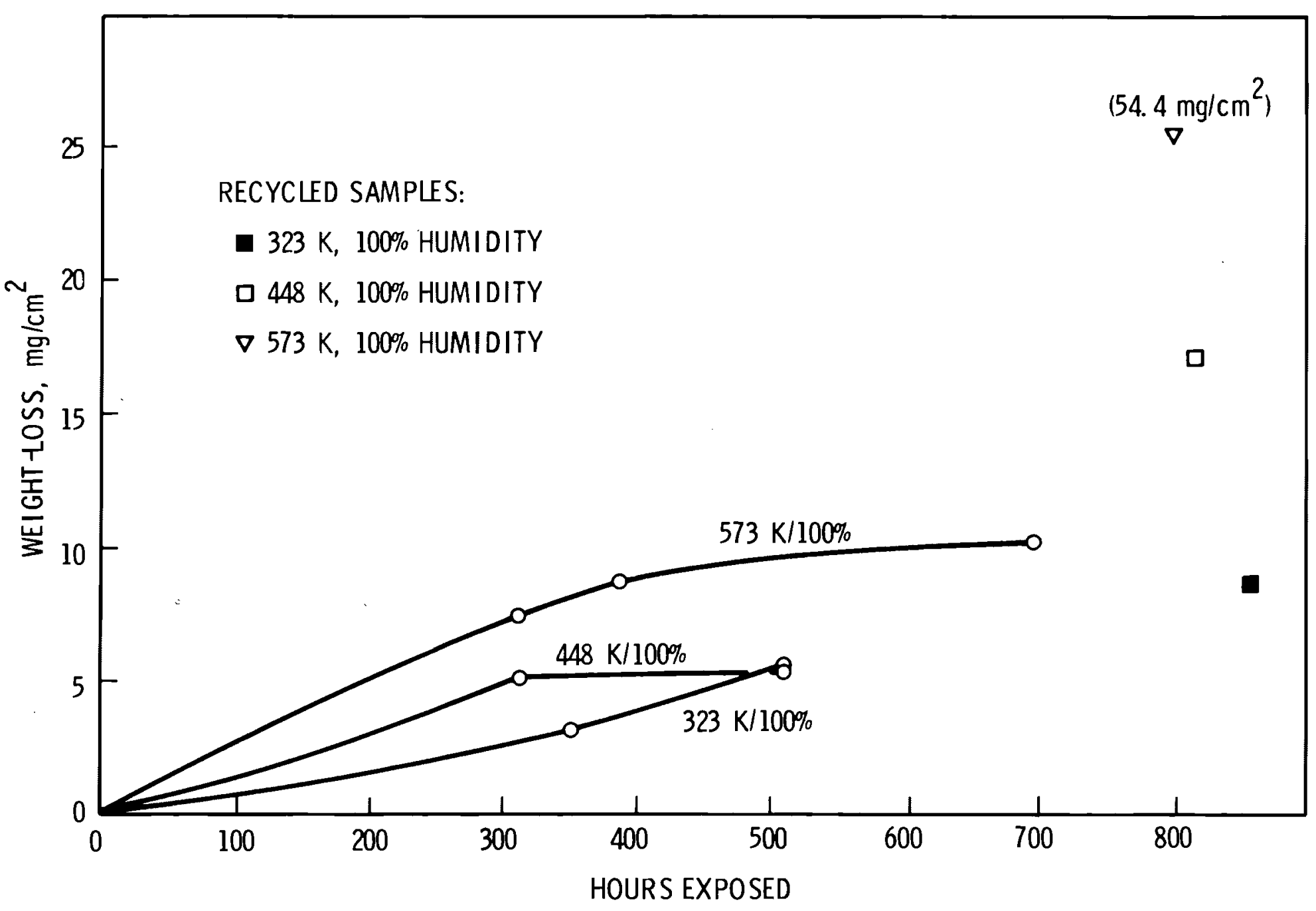

FIGURE 4. Corrosion as Weight Loss (mg) per Surface Area $\left(\mathrm{cm}^{2}\right)$ Versus Hours Exposed for Recycled Samples of Metal A120 


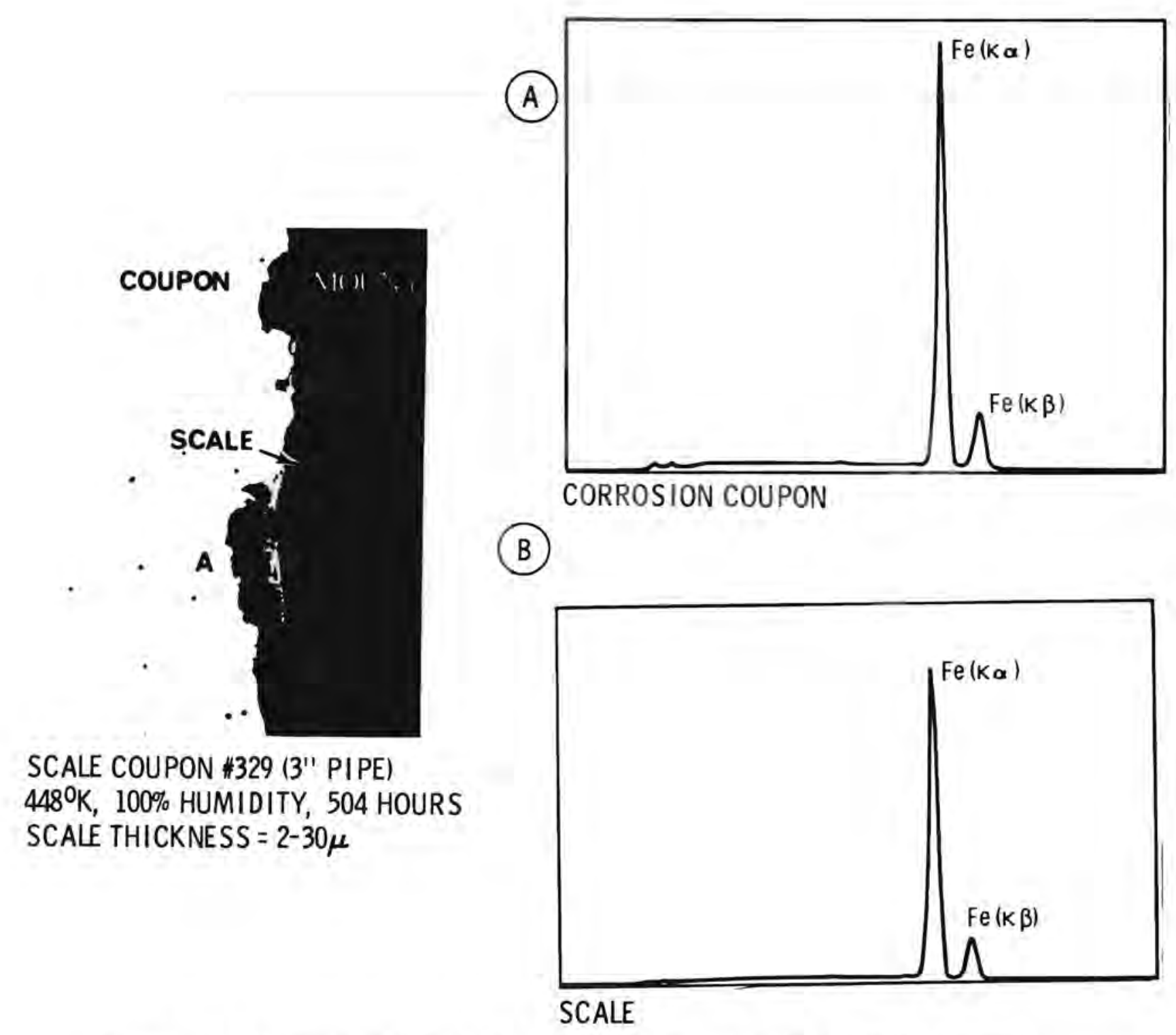

FIGURE 5. Cross-Sectional ETectron Microscopy of Corrosion Coupon 
The corrosion potential for some CAES well casing materials was measured after exposure to heated dry or humid air. Corrosion rates varied between 0.0015 and $0.15 \mathrm{~mm} / \mathrm{y}$; the literature had reported higher corrosion rates in similar environments. There are several factors that may have been present in the other studies that could increase the laboratory-determined corrosion rates:

- chemistry of the steam or water droplets

- cracking in the protective scale due to temperature or humidity changes

- sandstone-metal interactions

- higher $\mathrm{O}_{2}$ content.

In determining the effects of varying the salinity of the liquid phase, $\mathrm{NaCl}$ and $\mathrm{KCl}$ were added to the water reservoir. The metals were then tested at 448 and $573 \mathrm{~K}$ in this humid compressed air with salts. The results--corrosion rates of $0.0036-0.078 \mathrm{~mm} / \mathrm{y}$ (1.41-3.07 mpy, see Table 4)--are not enough higher to alter the acceptability of these metals. Thus, chemistry of the steam or water droplets does not appear to be significant. Scale cracking has already been discussed, and any removal of the protective scale will increase

TABLE 4. Corrosion Rates (mm/y) for Casing Materials Exposed in a $100 \%$ Humidity Environment Produced from Salt Solution Reservoir

\begin{tabular}{|c|c|c|}
\hline Pipe Casing & $448 \mathrm{~K}$ & $573 \mathrm{~K}$ \\
\hline A120 & $0.036 \pm 0.009(3)^{(a)}$ & $\overline{0.070 \pm 0.022(2)}$ \\
\hline H40 series & $0.056 \pm 0.013(3)$ & $0.078 \pm 0.015$ \\
\hline H53B & $0.064 \pm 0.008$ (3) & $0.063+0.001$ \\
\hline
\end{tabular}

Test conditions: $12.1 \mathrm{MPa}$ 336 hours exposure $0.50 \mathrm{~g} / 1 \mathrm{NaCl}+0.14 \mathrm{~g} / 1 \mathrm{KCl}$

(a) Data in mean averaged $\mathrm{m} / \mathrm{y} \pm 1$ standard deviation. Number of samples averaged given in parentheses. 
the corrosion rate of the metals. The corrosion rate of the casing in contact with the sandstone acquifer in heated compressed air was measured to be $0.15 \mathrm{~mm} / \mathrm{y}$ (5.99 mpy). Thus, there is a potential for corrosion on the outside of the casing, which is most likely due to crevice corrosion that occurs between the sandstone and the metal wall. Even though these laboratory simulations were under static conditions it was calculated that there was sufficient oxygen for oxidation of the metals. Using the ideal gas law as $12.1 \mathrm{MPa}$ and $573 \mathrm{~K}$ there was at least $17-\mathrm{g} \mathrm{O}_{2}$. Thus, higher $\mathrm{O}_{2}$ content is not a viable concern. 


\section{REFERENCES}

Barkman, J. H., and D. H. Davidson. July 1972. "Measuring Water Quality and Predicting Well Impairment." J. Petrol. Tech. 865.

Foster, P. K., T. Marshall, and A. Tombs. 1964. "Corrosion Investigations in Hydrothermal Media at Wairakei, New Zealand." Paper G/47 in United Nations Conference on New Sources of Energy, Rome, August 1961, Vol. 3, NY, United Nations, p. 186.

Marshall, T., and A. Hugill. May 1957. "Corrosion by Low-Pressure Geothermal Steam." Corrosion, National Association of Corrosion Engineers, Vol. 13, p. 329 .

Owen, L. B. 1979. Evaluating Brine Reinjection for DOE's Strategic Petroleum Reserve Program. Resource Applications.

Stottlemyre, J. A., R. L. Erikson, R. P. Smith. 1979. "Potential Petrophysical and Chemical Property Alterations in a Compressed Air Energy Storage Porous Rock Reservior." PNL-2974, Pacific Northwest Laboratory, Richland, Washington.

Tolivia, E., J. Hoaski, and M. Miyazaki. 1975. "Corrosion of Turbine Materials in Geothermal Steam Environment in Cerro Prieto, Mexico." In Proceedings of 2nd U.N. Symposium Development Use Geothermal Resources, p. 1815, San Francisco, California, May 3, 1975.

Toney, S., M. Cohen, and C. J. Cron. 1977. "Metallurgical Evaluation of Materials for Geothermal Power Plant Applications." Geothermal Energy 5(9):9. 


\section{BIBLIOGRAPHY}

The following documents have been issued or are in progress at PNL or its subcontractors and report the results of the work toward these objectives.

Allen, R. D., and P. J. Gutknecht. June 1980. Porous Media Experience Applicable to Field Evaluation for Compressed Air Energy Storage. PNL-3294, Pacific Northwest Laboratory, Richland, Washington.

Port-Keller, D. S., and P. R. Gnirk. 1980. CAES and UPHS in Hard Rock Caverns: I. Geological and Geotechnical Aspects. Re/Spec Inc., Rapid City, South Dakota. PNL-2286, Pacific Northwest Laboratory, Richland, washington.

Friely, J. R. January 1980. Structural Analysis of Porous Rock Reservoirs Subjected to Conditions of Compressed Air Energy Storage. PNL-3231, Pacific Northwest Laboratory, Richland, Washington.

Knutsen, C. A. September 1979. Incremental Cost Analysis of Advanced Concept CAES Systems. Knutsen Research Services, Bothell, Washington. PNL-3118, Pacific Northwest Laboratory, Richland, Washington.

Kreid, D. K. May 1976. Technical and Economic Feasibility Analysis of the No-Fuel Compressed Air Energy Storage Concept. BNWL-2065, Pacific Northwest Laboratory, Richland, washington.

Kreid, D. K., and M. A. McKinnon. March 1978. FY-1977 Progress Report Compressed Air Energy Storage Advanced Systems Analysis. PNL-2464, Pacific Northwest Laboratory, Richland, Washington.

Loscutoff, W. V. June 1979. Pacific Northwest Laboratory Annual Report for 1978 to the DOE Division of Energy Storage Systems - Compressed Air Energy Storage Technology Program, PNL-2935, Pacific Northwest Laboratory, Richland, washington.

Loscutoff, W. V. et al. June 1980. Compressed Air Energy Storage Technology Program Annual Report for 1979. PNL-3395, Pacific Northwest Laboratory, Richland, Washington.

Preliminary Report on Numerical Modeling of the Behavior of Caverns in Salt for Compressed Air Energy Storage (CAES) Part I - Literature and Data Base Review. 1980. Serata Geomechanics Inc., Berkeley, Cal if ornia. PNL-2287, Pacific Northwest Laboratory, Richland, Washington.

Preliminary Report on Numerical Modeling of the Behavior of Caverns in Salt for Compressed Air Energy Storage (CAES) Part II - Laboratory Testing. 1980. Serata Geomechanics Inc., Berkeley, California. PNL-2287, Pacific Northwest Laboratory. 
Schulte, S. C., and R. W. Reilly. November 1979. The Economics of Compressed Air Energy Storage Employing Thermal Energy Storage. PNL-3191, Pacific Northwest Laboratory, Richland, Washington.

Smith, G. C. March 1978. FY-1977 Progress Report - Stability and Design Criteria Studies for Compressed Air Energy Storage Reservoirs. PNL-2443, Pacific Northwest Laboratory, Richland, Washington.

Smith, G. C., L. E. Wiles, and W. V. Loscutoff. February 1979. Numerical Analysis of Temperature and Flow Effects in a Dry, One-Dimensiona 1 Aquifer Used for Compressed Air Energy Storage. PNL-2546, Pacific Northwest Laboratory, Richland, Washington.

Stottlemyre, J. A. June 1978. Preliminary Stability Criteria for Compressed Air Energy Storage in Porous Media Reservoirs. PNL-2685, Pacific Northwest Laboratory, Richland, Washington.

Stottlemyre, J. A., R. L. Erikson, and R. P. Smith. October 1979. Potential Petrophysical and Chemical Property Alterations in a Compressed Air Energy Storage Porous Rock Reservoir. PNL-2974, Pacif ic Northwest Laboratory, Richland, Washington.

Thoms, R. L., and J. D. Martinez. August 1978. Preliminary Long-Term Stability Criteria for Compressed Air Energy Storage Caverns in Salt Domes. PNL-2871, Pacific Northwest Laboratory, Richland, Washington.

Wiles, L. E. March 1979. The Effects of Water on Compressed Air Energy Storage in Porous Rock Reservoirs. PNL-2869, Pacific Northwest Laboratory, Richland, Washington.

Wiles, L. E. October 1979. Numerical Analysis of Temperature and Flow Effects in a Dry, Two-Dimensional, Porous-Media Reservoir Used for Compressed Air Energy Storage, PNL-3047, Pacific Northwest Laboratory, Richland, Washington. 


\section{DISTRIBUTION}

No. of

Copies

OFFSITE

A. A. Churm

DOE Patent Division

9800 South Cass Avenue

Argonne, IL 60439

5 U.S. Department of Energy

Attn: S. Strauch

Division of Thermal and

Mechanical Energy Storage

600 E Street, Room 416

Washington, D.C. 20585

U.S. Department of Energy

Attn: J. H. Swisher

Division of Thermal \& Mechanical

Energy Storage

600 E Street, Room 416

Washington, D.C. 20585

U.S. Department of Energy

Attn: J. Gahimer

Division of Thermal \& Mechanical

Energy Storage

600 E Street, Room 416

Washington, D.C. 20585

U.S. Department of Energy

Attn: Program Manager CS-66

Thermal Energy Storage Branch

Office of Energy Storage Systems

600 E Street

Washington, D.C. 20585

U.S. Department of Energy

Attn: G. F. Pezdirtz

Office of Advanced Conservation

Technologies

600 E Street, Room 416

Washington, D.C. 20585
No. of

Copies

5 U.S. Department of Energy

Attn: G. D. Karadi

Division of Thermal \& Mechanical

Energy Storage

600 E Street, Room 416

Washington, D.C. 20585

W. F. Kobett

CAES Project Manager

Westinghouse Electric Corp.

Cpmbustion Turbine Sys. Div.

Long Range Development-Lab 100

P.0. Box 251

Concordville, PA 19331

J. C. Smith

Division of Electrical Energy Systems

Department of Energy

12 \& Pennsylvania, Room 6144

Washington, D.C. 20585

J. Gahimer

Department of Energy

Division of Thermal and

Mechanical Energy Stroage

600 "E" Street, Room 416

Washington, D.C. 20585

C. Holt

Battelle Columbus Laboratories

505 King Avenue

Columbus, $\mathrm{OH} \quad 43201$

T. Bar low

Lawrence Livermore Laboratory

P.0. Box 808

Livermore, CA 94550

Distr-1 
No. of

Copies

H. M. Dodd

Organization 5743

Sandia Labs

Albuquerque, NM 87115

R. 0. Woods

Sandia Laboratories

Org. No. 4715

Alubquerque, NM 87115

J. L. Nash-Webber

MIT

Energy $L a b$

Cambridge, MA 02139

R. D. Lessard

United Technologies Research

Center

Silver Lane

East Hartford, CT 06108

M. J. Hobson

Acres American, Inc.

The Clark Bldg.

Suite 329

Columbia, MD 21044

Acres American, Inc.

Attn: D. Willett

Liberty Bank Building

Main at Court

Buffalo, NY 14202

Acres American, Inc.

Attn: M. J. Hobson

The Clark Building

Suite 329

Columbia, MD 21044

U.S. Army Corps of Engineers

Attn: Library

P.0. Box 59

Louisville, KY 40202
No. of

Copies

\author{
U.S. Army Corps of Engineers \\ Attn: Chief, Engineering \\ Division \\ P.0. Box 2870 \\ Portland, OR 97208
}

Battelle Columbus Laboratories

Attn: C. Holt

505 King Avenue

Columbus, $\mathrm{OH} 43201$

Bechtel Corporation

Attn: T. E. Walsh

50 Beale Street

San Francisco, CA 94105

Bechtel National Inc.

Attn: W. Stevens (50/20/B37)

Res \& Eng.

P.0. Box 3965

San Francisco, CA 94119

Boeing Engineering and

Construction Co.

Attn: W. W. Engle

Mail Stop 9A-40

P.0. Box 3707

Seattle, WA 98124

Bonneville Power Administraton

Attn: Manager, Research and Development

P.0. Box 3621

Portland, OR 97208

Brown Boveri Corporation

Attn: Stanley Stys

1460 Livingston Avenue

North Brunswick, NJ 08902

U.S. Dept of the Interior

Attn: Science and Technology Staff

Bureau of Reclamation

18 th and C Streets, NW

Washington, D.C. 20240 
No. of

Copies

27 DOE Technical Information Center

U.S. Department of Energy

Attn: Technical Info. Officer

Chicago Operations Office

9800 South Cass Avenue

Argonne, IL 60439

U.S. Dept of Energy

Attn: Director/CS-30

Division of Buildings and

Community Systems

Washington, D.C. 20585

U.S. Dept of Energy

Attn: Gerald Braun/CS-68

Solar Thermal Branch

Division of Central Solar

Technology

Washington, D.C. 20585

U.S. Department of Energy

Attn: Director/CS-21

Division of Policy Planning and Evaluation

Conservation and Solar Energy

Washington, D.C. 20585

U.S. Department of Energy

Attn: Director

ETEC Project Office

P.0. Box 1446

Canoga Park, CA 91304

U.S. Department of Energy

Attn: W. F. Heavey, Jr/RC-522

3341 Ferc Building

825 North Capitol Street, NE

Washington, D.C. 20426

U.S. Department of Energy

Attn: Director Research and

Technical Support Division

Oak Ridge Operations Office

P.0. Box E

Oak Ridge, TN 37830
No. of

$\underline{\text { Copies }}$

\section{U.S. Department of Energy \\ Attn: Director RA-234 \\ Office of Electric Energy Systems \\ 12 th and Pennsylvania Ave, NW}

Washington, D.C. 20461

U.S. Deparatment of Energy

Attn: Asst. Secretary for

Environment

1000 Independence Avenue, NW

Washington, D.C. 20585

U.S. Department of Energy

Attn: Director

Box 26500

Lakewood, CO 80226

U.S. Department of Energy

Attn: B. J. Mueller

Chicago Operations office

9800 S. Cass Avenue

Argonne, IL 60439

U.S. Department of Energy

Attn: D. W. Boehm

Division of Environmental

Safety and Engineering

MS-E201, Germantown

Washington, D.C. 20545

U.S. Department of Energy

Library

Mail Station G-043

Washington, D.C. 20585

U.S. Department of Energy

Library, Attn: R. F. Kimberlin

Room 1223

Washington, D.C. 20585

U.S. Department of Energy

Attn: L. J. Rogers

Division of Generation and

Storage Applications

12 Pennsylvania, Room 6144

Washington, D.C. 20585 
No. of

Copies

Dow Chemical Company

Attn: J. F. Mulloy

Midland, MI 48640

Electric Power Research Instit.

Attn: R. B. Schaninker

P.0. Box 10412

$3412 \mathrm{Hillview} \mathrm{Avenue}$

Palo Alto, CA 94304

Electric Power Research Instit.

Attn: A. Ferreira

c/O NEPLAN

174 Brush Hill Avenue

West Springfield, MA 01089

Rockwell International Corp.

Energy Systems Group

Attn: Dr. Harry Pear Iman

P.0. Box 309

Canoga Park, CA 91304

Exxon Research and Engineering Company

Attn: Mr. A. Skopp

P.0. Box 45

Linden, NJ 07036

Fenix and Scisson, Inc.

Attn: Douglas Anderson

1401 South Boulder Avenue

Tulsa, OK 74119

General Electric R\&D Center

Attn: D. H. Brown

Bldg 5, Rm, 345

P.0. Box 43

Schenectady, NY 12301

GPU Service Corporation

Attn: Director of Research

Parsippany, NJ 07054
No. of

Copies

Hooker Chemical and Plastics

Corporation

Attn: Dr. R. C. Johnson

P.0. Box 8

Niagara Falls, NY 14302

Illinois Power Company

Attn: Mr. G. E. Huck

Manager of Planning

500 South 27th St.

Decatur, IL 62525

Institute of Gas Technology

Attn: Library

3424 South State Street

IIT Center

Chicago, IL 60616

California Institute of Tech.

Attn: Vincent Truscello

Jet Propulsion Laboratory

4800 Oak Grove Drive

Pasadena, CA 91103

Lawrence Berkeley Laboratory

Attn: Library

University of California

Bldg 50, Room 134

Berkeley, CA 94720

Lawrence Livermore Laboratory

Attn: Tech. Info. Dept., $L-3$

University of Cal ifornia

P.0. Box 808

Livermore, CA 94550

Lawrence Livermore Laboratory

Attn: T. Barlow

P.0. Box 808

Livermore, CA 94550

Los Alamos Scientific Laboratory

Attn: Jim Blacic

G-6-LASL-Stop 978

P.0. Box 1663

Los Alamos, NM 87545 
No. of

Copies

Louisiana State University

Attn: R. L. Thoms

Institute for Environmental

Studies

Room 42, Atkinson Hall

Baton Rouge, LA 70803

Martin Marietta Company

Attn: Research Library

MS 2659

P.0. Box 179

Denver, C0 80201

Massachusetts Institute of Tech.

Attn: J. L. Nash-Webber

Energy Lab

Cambridge, MA 02139

Middle South Services

Attn: Lewis $A$. Wilson

P.0. Box 61000

New Orleans, LA 70161

National Bureau of Standards

Attn: Dr. Lewis H. Gevantman

Washington, DC 20234

National Science Foundation

Division of Advanced Energy

Research and Technology

Room 1140

1800 G Street, NW

Washington, DC 20550

Northern Illino is Gas Company

Attn: C. G. Nelson

Manager, Storage Operations

P.0. Box 190

Aurora, IL 60507

Oak Ridge National Laboratory

Attn: Dr. Herbert W. Hoffman P.0. Box $Y$

Oak Ridge, TN 37830
No. of

Copies

Ohio Edison Company

Attn: J. H. Carson, Manager

Advanced Engineering Programs

Department

76 South Main Street

Akron, $\mathrm{OH} 44308$

PB-KBB Inc.

Attn: H. Lorenzen

Subsurface Systems \& Technology

800 Commer ce Road West

Harahan, LA 70123

Potomac Electric Power Co

Attn: P. E. Schaub

1900 Pennsylvania Avenue

Washington, DC 20006

Power Authority of the

State of New York

Attn: Gerald I. Stillman

Research and Development

10 Columbus Circle

Public Service of Indiana

Attn: T. W. McCafferty

1000 E Main Street

Plainfield, IN 46168

Public Service Co. of New Mexico

Attn: Ely Yao, Manager

Resource Development and

Technical Services

Albuquerque, NM 87103

$\mathrm{Re} / \mathrm{Spec}$ Inc.

Attn: Paul Gnirk

P.0. Box 725

Rapid City, SD 57701

Rensselaer Polytechnic Institute

Attn: G. J. Jantz

Molten Salt Data Center

Troy, NY 12181 
No. of

Copies

Rocket Research Corporation

Attn: Doug Huxtable

York Center

Redmond, WA 98052

Rockwell International Corp.

Attn: TIC BA29

Rocketdyne Division

6633 Canoga Ave

Canoga Park, CA 91304

Sandia Laboratories

Attn: Tech. Library Div. 3141

Albuquerque, NM 87175

Sandia Laboratories

Attn: H. M. Dodd

Organization 5743

Albuquerque, NM 87115

Sandia Laboratories

Attn: R. 0. Woods

Organization 4715

Albuquerque, NM 87115

Sargent and Lundy Engineers

Attn: Mr. W. C. Walke

Project Manager

55 East Monroe Street

Chicago, IL 60603

Science Application Inc.

Attn: Mort Blatt

P.0. Box 2351

La Jolla, CA 92038

Serata Geomechanics, Inc.

Attn: S. Serata

1229

Eighth Street

Berkeley, CA 94710

Soyland Power Cooperative, Inc.

Attn: Royal B. Newman

P.0. Box A1606

Decatur, IL 62525
No. of

Copies

Tennessee Valley Authority

Energy Research Section

1360 Commerce Union Bank Bldg

Chattanooga, TN 37401

Tennessee Valley Authority

Attn: Gerald Phillips

1150 Chestnut, Tower 2

Chattanooga, TN 37401

Terra Tek Inc.

Attn: C. Cooley

University Research Park

400 Wakara Way

Salt Lake City, UT 84108

TRW Energy Systems Group

Attn: E. Berman

Technical Library

7600 Colshire Drive

McLean, VA 22101

Texas A \& M University

Attn: R. R. Davison

Chemical Eng. Dept.

College Station, TX 77843

Union Carbide Corporation

Nuclear Division

Attn: Library

PO Box $Y$

Oak Ridge, TN 37830

Union Electric Co.

Attn: George C. Wagner

Manager, Special Projects

Mail Code 916

P.0. Box 149

St Louis, MO 63166

Union Electric Co.

Attn: E. M. Mabuce

Manager - Applied Research

Corporate Planning Dept.

P.0. Box 149

St. Louis, MO 63166 
No. of

Copies

United Engineers and Contractors Inc.

Attn: George Englesson

Advanced Engineering Dept.

P.0. Box 8223

Philadelphia, PA 19101

United Technologies Research Center

Attn: Albert I. Giramonti

Silver Lane

East Hartford, CT 06108

United Technologies Research

Center

Attn: R. D. Lessard

Silver Lane

East Hartford, CT 06108

United Technologies Research Center

Attn: Library

400 Main Street

East Hartford, CT 06108

Auburn University

Attn: James C. Warman

Water Resource Research Institute

Auburn, AL 36830

University of California

Attn: T. L. Brekke

Department of Civil Engineering

1847 Yosemite Road

Berkeley, CA 94707

University of California

Attn: T. L. Belle

Department of Civil Engineering

1847 Yosemite Road

Berkeley, CA 94707

University of Massachusetts

Attn: 0. C. Farquhar

Dept. of Geology \& Geography

Morrill Science Center

Amherst, MA 01003
No. of

Copies

University of Michigan

Attn: Donald L. Katz

Dept. of Chemical Engineering

2042 E. Engr. Bldg.

Ann Arbor, MI 48109

University of Wisconsin

Attn: H. J. Pincus

Dept. of Geological Sciences

Sabin $\mathrm{Hall}$ and Greene Museum

P.0. Box 413

Milwaukee, WI 53201

Westinghouse Electric Corp.

Attn: Gene Pierson

Long Range Development Dept.

P.0. Box 251

Mail Stop 260

Concordville, PA 19331

Westinghouse Electric Corp.

Attn: W. F. Kobett

CAES Project Manager

Combustion Turbine Sys. Div.

Long Range Develop-Lab 100

P.0. Box 251

Concordville, PA 19331

Westinghouse Electric Corp.

Attn: D. Ayers

Manager, Fluid Systems

Laboratory

1291 Cumber land Avenue

West Lafayette, IL 47906

FORE IGN

Commonwealth Science and Industrial Research Org.

Attn: Robert V. Dunkle

Division of Mechanical

Engineering

3190 Graham Road

Highett, Victoria, Australia 
No. of

Copies

National Building Research Institute

Attn: J. F. Van Straaten

Industrial Research

P.0. Box 395

Pretoria, South Africa 0001

National Swedish Board for Energy Source Development

Attn: Jackie Bergman

Box 21048

S-10031 Stockholm 21, Sweden

ONSITE

DOE Richl and Operations Office

D. K. Jones

H. E. Ransom
No. of

Copies

35 Pacific Northwest Laboratory

R. D. Allen

R. L. Dillion

T. J. Doherty

M. K. Drost

S. K. Edler

R. L. Erikson

J. A. Fort

J. R. Friley

P. J. Gutknecht

L. D. Kannberg

W. V. Loscutoff

R. P. Marshall

R. A. McCann

M. A. Mckinnon

L. T. Pedersen

R. W. Reilly

R. P. Smith (5)

J. A. Stottlemyre (5)

A. M. Sutey

L. E. Wiles

Technical Information (5)

Publishing Coordination (2) 